\title{
Using the Storm Water Management Model to predict urban headwater stream hydrological response to climate and land cover change
}

\author{
J. Y. Wu ${ }^{1}$, J. R. Thompson ${ }^{1}$, R. K. Kolka ${ }^{2}$, K. J. Franz ${ }^{3}$, and T. W. Stewart ${ }^{1}$ \\ ${ }^{1}$ Department of Natural Resource Ecology and Management, Iowa State University, Ames, IA, USA \\ ${ }^{2}$ Center for Research on Ecosystem Change, USDA Forest Service, Grand Rapids, MN, USA \\ ${ }^{3}$ Department of Geological and Atmospheric Sciences, Iowa State University, Ames, IA, USA
}

Correspondence to: J. R. Thompson (jrrt@iastate.edu)

Received: 15 May 2013 - Published in Hydrol. Earth Syst. Sci. Discuss.: 4 June 2013

Revised: 26 August 2013 - Accepted: 27 October 2013 - Published: 3 December 2013

\begin{abstract}
Streams are natural features in urban landscapes that can provide ecosystem services for urban residents. However, urban streams are under increasing pressure caused by multiple anthropogenic impacts, including increases in human population and associated impervious surface area, and accelerated climate change. The ability to anticipate these changes and better understand their effects on streams is important for developing and implementing strategies to mitigate potentially negative effects. In this study, stream flow was monitored during April-November (2011 and 2012), and the data were used to apply the Storm Water Management Model (SWMM) for five urban watersheds in central Iowa, USA, representing a gradient of percent impervious surface (IS, ranging from 5.3 to $37.1 \%$ ). A set of three scenarios was designed to quantify hydrological responses to independent and combined effects of climate change (18\% increase in precipitation), and land cover change (absolute increases between 5.2 and $17.1 \%$, based on separate projections of impervious surfaces for the five watersheds) for the year 2040 compared to a current condition simulation. An additional set of three scenarios examined stream response to different distributions of land cover change within a single watershed. Hydrological responses were quantified using three indices: unit-area peak discharge, flashiness $(R-B$ Index; Richards-Baker Index), and runoff ratio. Stream hydrology was strongly affected by watershed percent IS. For the current condition simulation, values for all three indices were five to seven times greater in the most developed watershed compared to the least developed watershed. The cli-
\end{abstract}

mate change scenario caused a $20.8 \%$ increase in unit-area peak discharge on average across the five watersheds compared to the current condition simulation. The land cover change scenario resulted in large increases for all three indices: $49.5 \%$ for unit-area peak discharge, $39.3 \%$ for $R-B$ Index, and $73.9 \%$ for runoff ratio, on average, for the five watersheds. The combined climate and land cover change scenario resulted in slight increases on average for $R-B \mathrm{In}$ dex $(43.7 \%)$ and runoff ratio $(74.5 \%)$ compared to the land cover change scenario, and a substantial increase, on average, in unit area peak discharge $(80.1 \%)$. The scenarios for different distributions of land cover change within one watershed resulted in changes for all three indices, with an $18.4 \%$ increase in unit-area peak discharge for the midstream scenario, and $17.5 \%$ (downstream) and $18.1 \%$ (midstream) increases in $R-B$ Index, indicating sensitivity to the location of potential additions of IS within a watershed. Given the likelihood of increased precipitation in the future, land use planning and policy tools that limit expansion of impervious surfaces (e.g. by substituting pervious surfaces) or mitigate against their impacts (e.g. by installing bioswales) could be used to minimize negative effects on streams.

\section{Introduction}

The hydrology of urban streams is responsive to human activities in the surrounding landscape (Arnold and Gibbons, 1996; Walsh et al., 2005; Wenger et al., 2009). Compared 
to streams in more natural settings, urban streams are located in landscapes associated with less infiltration and more surface runoff, often leading to greater peak discharge and shorter peak discharge lag times (Anderson, 1970; Arnold and Gibbons, 1996). Declines in stream water quality and ecological condition, such as increases in pollutant and nutrient concentrations (e.g. Hatt et al., 2004; Pekarova and Pekar, 1996), and shifts in organismal assemblages to more eutrophic species (e.g. Black et al., 2011; Walsh et al., 2001) have commonly been reported for urban streams. Accelerated climate change (Denault et al., 2006), land use and land cover change (Grimm et al., 2008), and combinations of such changes (Nelson et al., 2009; Tong et al., 2012) are thought to be among the major driving factors leading to rapid degradation of urban stream systems.

Computer-based hydrological models have been used to better understand urban stream responses to potential stressors, such as projected changes in climatic conditions and land cover. Frequently used models include the Storm Water Management Model (or SWMM; Rossman, 2010; US EPA, 2011), the Hydrological Simulation Program-Fortran model (HSPF; Bicknell et al., 1997), and the Soil and Water Assessment Tool (SWAT; Neitsch et al., 2002), which can be used to predict hydrological responses to user-designed scenarios at relatively low cost. Of these models, SWMM has been applied in studies of urban streams because of its ability to simulate the hydraulic dynamics of artificial drainage systems that are prevalent in urban areas (e.g. Denault et al., 2006; Hsu et al., 2000; Meierdiercks et al., 2010). SWMM was developed to enable appropriate design of drainage systems (e.g. sizing for detention features, evaluating effectiveness of different runoff control strategies) and can be used to simulate dynamics of single events or for modeling on a continuous basis (US EPA, 2011). The model incorporates precipitation data to simulate surface runoff and pollutant outputs for sub-catchment areas which are then conveyed to the watershed outlet by a user-designated drainage system (US EPA, 2011).

Studies using hydrological models to predict stream response to changes in precipitation amounts and delivery patterns have used a variety of techniques to generate future scenarios (as reviewed by Praskievicz and Chang, 2009). For example, in assessments of streamflow responses to climate change, global climate models (GCMs) and regional climate models (RCMs) have been used (e.g. Chang, 2003; Jha et al., 2004; Nelson et al., 2009; Poelmans et al., 2011; Takle et al., 2010; Quilbe et al., 2008). However, the grid scales commonly used in GCMs (hundreds of km; Boyle, 1998) and RCMs ( $\sim 50 \mathrm{~km}$; Takle et al., 2010$)$ and their time intervals ( $\geq$ hourly; Kendon et al., 2012) are not suitable for predictions at finer spatio-temporal scales. Other approaches that have been used at more local scales and for shorter time intervals include linear regression based on historical precipitation records (Denault et al., 2006; Takle and Herzmann, 2010) or projections based on likely proportional changes, for example, $\pm 20 \%$ of current precipitation (Tong et al., 2012).

Similarly, a variety of approaches have been used to create projections for land cover change, including those based on Markov-chain probability models that generate both quantity and location of additional impervious surfaces (such as the software package Land Change Modeler; Eastman, 2012, as used by Bowman et al., 2012). Alternatively, logistic regression-based methods that incorporate historical land cover analyses combined with socioeconomic (population, land value) driver variables have also been used (Guneralp et al., 2012; Serneels and Lambin, 2001). A third approach that has been used to predict land cover change is based on simple regression of historical changes in percent of developed land projected to a specified time in the future (Tu, 2009). Unlike the first two methods, land cover change using the third method is influenced only by the historical land cover characteristics, such as percent impervious surface (IS).

Some of the previously described prediction methods have been applied to investigate hydrological responses to climate change alone (Denault et al., 2006; Jha et al., 2004; Takle et al., 2010), land cover change alone (Meierdierks et al., 2010; Nagy et al., 2012; Rose and Peters, 2001) or to combined climate and land cover changes (e.g. Chen et al., 2005; Choi, 2008; Chung et al., 2011; Cuo et al., 2009; Hamdi et al., 2011; Tong et al., 2012; Yang et al., 2010). In general, these researchers reported greater variability in discharge (flashiness) and greater pollutant loading in response to increases in IS and/or precipitation. For example, Chang (2003) used two GCMs (the Canadian Centre model and Hadley Centre model) to predict climate change in conjunction with an empirical urban growth scenario to predict land cover change for the 2030s in the Conestoga River basin in Pennsylvania, USA. Predicted hydrological responses, simulated using the AVGWLF (ArcView Generalized Watershed Loading Function) model, indicated a $14 \%$ decrease in mean annual streamflow using the Canadian Centre model versus an $11 \%$ increase using the Hadley Centre model. Predicted streamflow for the whole basin increased by only $0.4 \%$ for a $15.5 \%$ increase in urban land area. Chung et al. (2011) investigated an integrated approach using a downscaling model (SDSM) with HSPF and the Impervious Cover Model (ICM) to predict flow and pollutant concentration in the Anyangcheon watershed in Korea under three climate conditions and three land use change scenarios. They concluded that climate change had greater effects in terms of increasing flow rates, and that land cover change had greater effects in terms of increasing stream water pollutant concentration. Poelmans et al. (2011) used statistical downscaling of $58 \mathrm{GCM} / \mathrm{RCM}$ runs to predict future climate scenarios and three different urban growth rates to predict outcomes for the 2050s in a small suburban catchment in the FlandersBrussels region, Belgium. Their lumped hydrological model simulated an $18 \%$ decrease in peak discharge under a projected dry scenario and a $30 \%$ increase in peak discharge 
under a wet summer scenario. Land cover change scenarios predicting increases in developed land ranging from 70 to $200 \%$ resulted in increases of peak discharge that ranged from $6-16 \%$.

In a growing number of studies, urban stream responses to climate and/or land cover change have been examined for multiple watersheds. For example, using the AVGWLF model, Tu (2009) predicted future climate and land cover changes and examined responses for streamflow and nitrogen loads at seven study sites in and near Boston, Massachusetts. Model outputs indicated that the greatest impacts from climate and land cover change were related to the seasonal distribution of discharge rate and nitrogen loading in the future, which were projected to be greater in fall and winter and lower in the summer, rather than affecting the average total annual amounts. In another study, Nagy et al. (2012) observed hydrological and water quality differences among 13 small watersheds located along the Florida Gulf Coast with different watershed percent IS. These researchers reported increases in peak flow, flashiness, $\mathrm{pH}$, and specific conductance as impervious surface in the watershed increased (Nagy et al., 2012).

Thus, there is considerable variation in predicted outcomes for climate change, land cover change, and their potential impacts on streams (Praskievicz and Chang, 2009). Previous research in the Midwest, however, consistently indicates a strong likelihood of increased storm intensity and total precipitation delivery in this region (Jha et al., 2004; Takle et al., 2010). Further, it has been suggested that small basins may experience greater impacts than larger ones (Praskevicz and Chang, 2009). The potential impacts of these changes on small streams in urban areas require additional investigation in order to better elucidate their separate and combined effects and to identify appropriate mitigation strategies. In the research described in this paper, we examined five watersheds from among 20 small urban headwater streams for which we collected water quality and water quantity data over two years, 2011 and 2012. The five watersheds were purposefully selected to represent a gradient of percent IS, ranging from 5.3 to $37.1 \%$. Climate and land cover change were projected to the year 2040 using regressions based on historical data. We then used SWMM to create hydrological models for these watersheds to answer the following questions:

1. What hydrological differences can be detected among the five urban headwater streams along a \% IS gradient?

2. What are the hydrological responses to projected climate change, land cover change, and combined climate and land cover change for these stream systems?

3. How might different distributions of land cover change affect urban headwater stream hydrology?

\section{Methods}

\subsection{Study area}

Five headwater stream watersheds located in Polk County, Iowa, USA, were included in this study (WS1 to WS5; Fig. 1). These watersheds were within the corporate boundaries of four cities: Altoona, Ankeny, Johnston and Pleasant Hill. These cities are located close to Iowa's state capital (Des Moines), and have experienced rapid population growth in recent years. Between 2000 and 2010, populations in Altoona, Ankeny, Johnston, and Pleasant Hill increased by $41 \%, 68 \%, 100 \%$, and $73 \%$, respectively, compared to a $4 \%$ increase for Iowa as a whole (State Data Center of Iowa, 2012). The five watersheds were located within the upper Midwest climatic region, with average annual precipitation over the most recent $25 \mathrm{yr}$ (1987-2011) of $805 \mathrm{~mm}$ (National Climatic Data Center, 2012). About $75 \%$ of annual precipitation typically occurs between April and September. The watersheds were located along the southern edge of the Des Moines Lobe landform region, a recently glaciated area (14 kyr BP) in which stream network development is ongoing. The watersheds were approximately $280 \mathrm{~m}$ above sea level.

Watersheds exhibited variation in size, initial percent IS, and average slope (Table 1). Two of the watersheds (WS1 and WS2) were located in Pleasant Hill (Fig. 1). Land cover in WS1 included residential development (clustered in the upstream area), agricultural land (midstream area), and pasture land (downstream area). The second watershed (WS2) contained a segment of US Highway 65 and was otherwise dominated by agricultural and forested areas. The third watershed (WS3) was in northeastern Altoona, along the eastern boundary of the city, and it contained residential, commercial, and agricultural land. The fourth watershed (WS4) was located in Johnston, and the fifth (WS5) was in Ankeny. Both WS4 and WS5 contained primarily residential areas. Although their drainage densities were similar, WS4 was characterized by a lower \% IS than WS5.

\subsection{Stream monitoring methods and other data sources}

Flow rates were measured twice per month from April to October at defined channel cross sections near each stream outlet using a FLO-MATE 2000 Water Current and Flowmeter $^{\mathrm{TM}}$ (Hach Company, Loveland, CO). Discharge was then determined using the cross-section method of Rantz (1982). Area of the defined channel cross section was determined by measuring stream depth at evenly distributed points (varying from one to seven) and multiplying by width. The maximum distance between adjacent measuring points was $0.5 \mathrm{~m}$.

In addition, stream stage was continuously recorded at 5 min intervals from mid-May to October at each cross section using HOBO U20 water level data loggers (Onset 

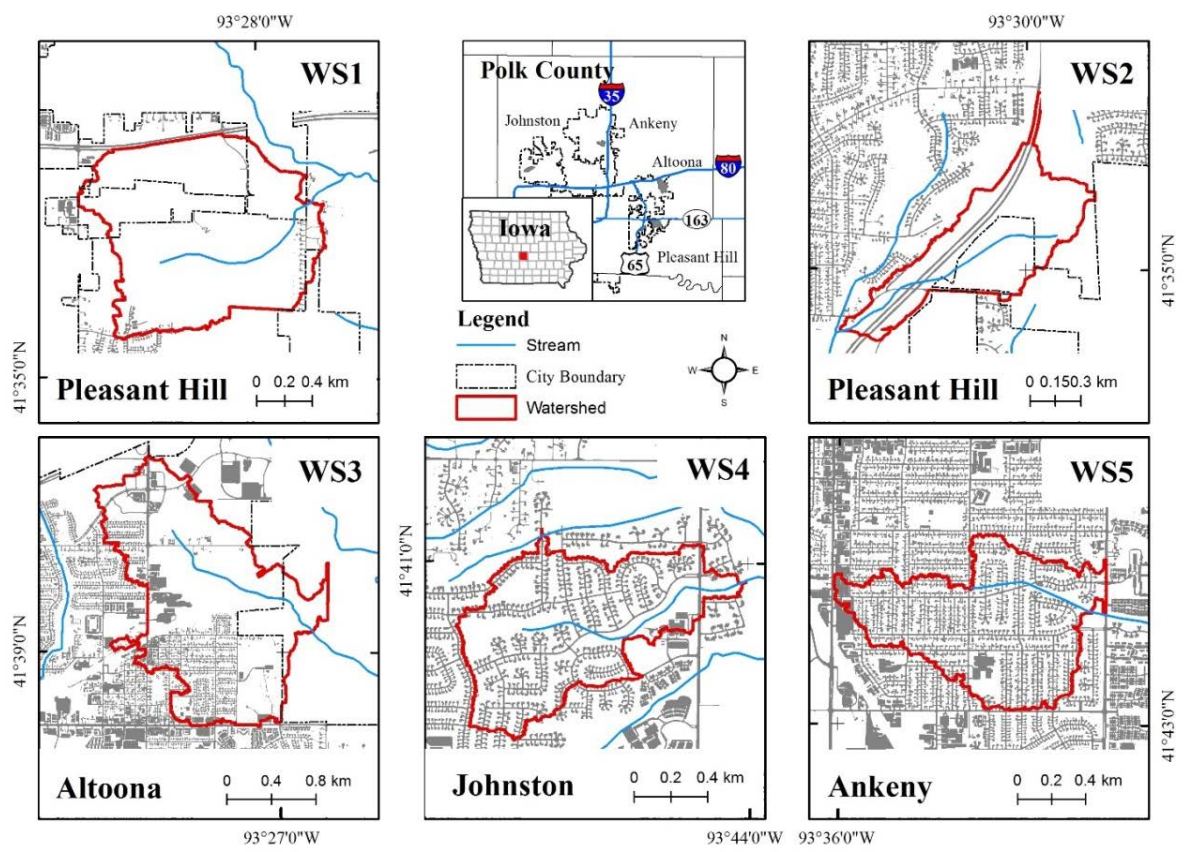

Fig. 1. Five headwater stream watersheds located in four cities (one each in Altoona, Ankeny, and Johnston, and two in Pleasant Hill) in Polk County, central Iowa. Shaded areas represent impervious surface in 2011, watershed boundaries for WS1 through WS5 are outlined with red lines.

Table 1. Geographic characteristics, drainage density, distance to nearest weather station, and projected percent impervious surface (IS, 2040) for five urban watersheds (WS1 to WS5) in central Iowa representing a percent impervious surface gradient. Total drainage density is the sum of road gutter, storm sewer and surface channel densities.

\begin{tabular}{lrrrrr}
\hline & WS1 & WS2 & WS3 & WS4 & WS5 \\
\hline Area (ha) & 194.9 & 61.8 & 269.8 & 89.5 & 92.0 \\
Current percent IS & 5.3 & 8.0 & 18.2 & 28.3 & 37.1 \\
Average slope (\%) & 10.3 & 5.4 & 5.6 & 10.5 & 8.8 \\
Total drainage density $\left(\mathrm{km} \mathrm{km}^{-2}\right)$ & 3.2 & 10.7 & 5.1 & 9.0 & 8.8 \\
Road gutter density $\left(\mathrm{km} \mathrm{km}^{-2}\right)$ & - & - & 0.6 & 0.3 & 0.3 \\
Storm sewer density $\left(\mathrm{km} \mathrm{km}^{-2}\right)$ & 0.2 & - & 1.3 & 6.7 & 6.5 \\
Surface channel density $\left(\mathrm{km} \mathrm{km}^{-2}\right)$ & 3.0 & 10.7 & 3.3 & 2.0 & 1.9 \\
Distance to nearest weather station $(\mathrm{km})$ & 10.4 & 5.8 & 15.0 & 5.3 & 3.1 \\
\hline Land cover projection & & & & & \\
Percent IS in 2040 & 10.5 & 15.7 & 35.3 & 45.0 & 45.0 \\
Absolute change $(\%)$ & 5.2 & 7.8 & 17.1 & 16.7 & 7.9 \\
Relative change $(\%)$ & 97.6 & 97.7 & 93.7 & 59.1 & 21.2 \\
\hline
\end{tabular}

Computer Corporation, Inc., Pocasset, MA). An additional data logger was used to measure barometric pressure for correction of stream stage data. Continuous stage data were converted to discharge using a stage-discharge rating curve developed for each stream.

Digital elevation models (DEMs) at one-meter resolution were generated from light detection and ranging (lidar) data available from the Iowa LiDAR Mapping Project (GeoTREE, 2011). Impervious surface cover for each watershed was manually digitized based on 2011 aerial photo images. Storm sewer GIS layers were obtained from staff members in the four cities. Five-minute interval precipitation data were obtained from Iowa SchoolNet system (Iowa Environmental Mesonet, 2012). Three weather stations were selected based on proximity to the five watersheds, "SDRI4" in Des Moines (for WS1, WS2, and WS3), "SGRI4" in Johnston (for WS4), and "SAKI4" in Ankeny (for WS5). 


\subsection{Calibration and validation of the Storm Water Management Model}

The Storm Water Management Model (SWMM Version 5.0.022; Rossman, 2010; US EPA, 2011) was used to simulate current and projected watershed conditions. Subcatchments were delineated to collect precipitation, and the kinematic wave method (Rossman, 2010) was used to route water through designated channels or pipes. Individual models were constructed for each of the five watersheds using 5 min interval precipitation data to simulate surface runoff and channelized discharge in road gutters, storm sewers, and surface channels. The embedded groundwater module was activated for all models using the same precipitation event ( $6.4 \mathrm{~mm}$ delivered to each watershed $5 \mathrm{~h}$ before each simulation) to "recharge" groundwater. Because we were interested in flow dynamics associated with single precipitation events, the effects of evaporation were not included (Gironás et al., 2009). Infiltration processes were simulated using Horton's equation within the model (Green, 1986).

Model parameters were obtained in three different ways. The first set of parameters were defined based on existing data for sub-catchment and drainage structure parameters, $\%$ IS, and slope. The second set of parameters were calibrated using available discharge observations, sub-catchment width, coefficients for groundwater equations, and Manning's roughness coefficient $(n)$ for impervious surfaces, pervious surfaces, and channels. All other parameters were set to default values or values suggested by the SWMM application manual (Gironás et al., 2009). For example, the initial infiltration rate was $100 \mathrm{~mm} \mathrm{~h}^{-1}$, the constant infiltration rate was $7 \mathrm{~mm} \mathrm{~h}^{-1}$, and the decay constant was 3.5 for Horton's infiltration equation.

Precipitation events (26 June 2011) recorded at the three weather stations were chosen to use for the calibration process. Precipitation depths were $8.9 \mathrm{~mm}$ (WS1, WS2, and WS3), $10.4 \mathrm{~mm}$ (WS4), and $12.7 \mathrm{~mm}$ (WS5). The models were then manually calibrated for best fit to the continuous discharge data derived from field monitoring for the same events. Precipitation events from the three weather stations on another date (25 May 2011) were used to validate the models. Precipitation depths for the validation procedure were $21.3 \mathrm{~mm}$ (WS1, WS2, and WS3), and $23.1 \mathrm{~mm}$ (WS4 and WS5).

Model performance was quantified using the coefficient of determination $\left(R^{2}\right)$ and Nash-Sutcliffe model efficiency coefficient (NSE). The coefficient of determination ranges from 0 to 1 , where greater values indicate a closer relationship between predicted and observed values for discharge. The NSE statistic has a range of $-\infty$ to 1 . A greater value indicates a better prediction of discharge, shown in Eq. (1):

$\mathrm{NSE}=1-\frac{\sum\left(Q_{\mathrm{o}, \mathrm{t}}-Q_{\mathrm{m}, \mathrm{t}}\right)^{2}}{\sum\left(Q_{\mathrm{o}, \mathrm{t}}-Q \mathrm{o}\right)^{2}}$ where NSE is the Nash-Sutcliffe model efficiency coefficient, $Q_{\mathrm{o}, \mathrm{t}}$ is the observed discharge $\left(\mathrm{m}^{3} \mathrm{~s}^{-1}\right)$ at time $t, Q_{\mathrm{m}, \mathrm{t}}$ is the modeled discharge $\left(\mathrm{m}^{3} \mathrm{~s}^{-1}\right)$ at time $t$, and is the average for the observed discharge $\left(\mathrm{m}^{3} \mathrm{~s}^{-1}\right)$.

\subsection{Climate change projection}

Our projections for climate change were based solely on changes in precipitation quantities delivered to each watershed. A precipitation event occurring on 10 June 2011 was used as the current climate condition for all five watersheds. This event delivered $16.8 \mathrm{~mm}$ of precipitation in one hour, representing a $1 \mathrm{~h}, 2$-month recurrence interval event in this region. We chose this event because it represents a common precipitation event, would not be likely to induce flooding (which would preclude estimates of response variables that describe flow dynamics within the channel), and was intermediate between the calibration (approximately $11 \mathrm{~mm}$ ) and validation (approximately $22 \mathrm{~mm}$ ) events, reducing some of the uncertainty associated with the hydrological projections. We based our projection on a simple linear regression model, and we do not assume that precipitation increases would necessarily be uniform throughout the year, but we have used the general projection to create a single hypothetical future event. Further, although other methods could be used to generate future precipitation scenarios, the spatio-temporal resolution of even regional climate downscaling models is relatively coarse for application at headwater stream/single event scales. To create a future (2040) precipitation event, annual precipitation for the region was obtained for the period 1895 to 2011 (National Climatic Data Center, 2012). Using linear regression (similar to method of Denault et al., 2006; Takle and Herzmann, 2010), annual precipitation in 2040 was projected to be $18 \%$ more than it was during 2011 . This proportional increase is consistent with results reported for this region of study by previous researchers (e.g. Jha et al., 2004; Takle et al., 2010). The projected precipitation event was designed to have the same duration and time distribution as the precipitation event on 10 June 2011.

\subsection{Land cover change projection}

Our assessment of future land cover change impacts was based solely on predicted changes in impervious surface cover in each of the study watersheds. Percent IS in 2011, calculated by dividing IS area within each watershed by the corresponding total watershed area, was used as the current land cover condition (again using the current condition 10 June 2011 rainfall event). Land cover was projected to the year 2040 using separate regression models based on quantification of total IS areas for each of the four cities (Altoona, Ankeny, Johnston, and Pleasant Hill) in 1940, 1961, 1990, 2002, and 2011 (method adapted from Tu, 2009). Binomial curves provided the best fit for the four cities, with coefficients of determination $\left(R^{2}\right)$ of 0.997 (Altoona), 0.984 
(Ankeny), 0.973 (Johnston), and 0.994 (Pleasant Hill). The increase of IS area within each watershed (Table 1) was assumed to be the same as that for each city, unless the projected $\%$ IS for the watershed exceeded $45 \%$ (which we set as a maximum according to the \% IS for other fully developed residential areas in our study area). We used a semidistributed approach to increase percent impervious surface by the projected amount within each sub-catchment of each watershed by adjusting the values for each of them in the input file for each model. We did not change the amount or distribution of storm sewer infrastructure for this analysis. For the land cover change simulation that included all five watersheds, increases in IS area were evenly distributed across each watershed.

\subsection{SWMM simulations with independent and combined effects of climate and land cover change}

We conducted current condition SWMM simulations using a single precipitation event (10 June 2011, $16.8 \mathrm{~mm}$ precipitation in one hour) and 2011 land cover data in all of the calibrated SWMM models (Table 2). A set of three different climate and land cover change scenarios were designed for this part of the study. In the first scenario, we used a precipitation event projected for 2040 with actual 2011 land cover. In the second scenario, we used the actual 2011 precipitation events and the projected land cover for 2040. In the third scenario, we used 2040 projections for both climate and land cover.

\subsection{SWMM simulations with different distributions of land cover change in a single watershed}

To assess effects of different distributions of future land cover changes, one watershed (WS4) was divided into three sections (Fig. 2). We chose WS4 because it initially had evenly distributed IS and was projected to have a relatively large IS increase. The three sections were downstream, midstream, and upstream areas within the watershed, and characterized by similar size and initial \% IS (2011). In this watershed, existing impervious surfaces (2011) were relatively evenly distributed between $10 \%$ and $95 \%$ distances to the watershed outlet. The same increase in urban land cover (to cause a $16.7 \%$ absolute increase for each section) was applied within one of the three sections, changing the impervious surface distribution from upstream to downstream. The projected precipitation event for 2040 in WS4 was used for each simulation in this set of scenarios.

\subsection{Quantifying hydrological indices}

To quantify hydrological responses, three indices were calculated for current condition and scenario simulations, including unit-area peak discharge, Richards-Baker Index (hereafter $R-B$ Index; Baker et al., 2004), and runoff ratio. Unitarea peak discharge is the quotient of peak discharge divided by watershed area, and indicates the greatest amount of discharge generated by a unit area in a single precipitation event. A greater value of peak discharge indicates greater potential for flooding (Huong and Pathirana, 2013). The $R-B$ Index measures oscillations in discharge relative to total discharge, also referred to as "flashiness". A higher value of the $R-B$ Index indicates a greater difference between high and low flows, which may be linked to changes in channel morphology, water quality and habitat structure of stream ecosystems (Shields et al., 2010; Violin et al., 2011). We calculated the $R-B$ Index based on $5 \mathrm{~min}$ interval discharge data, as per Eq. (2):

R-B Index $=\frac{\sum_{i=1}^{n}\left|q_{i}-q_{i-1}\right|}{\sum_{i=1}^{n} q_{i}}$,

where $n$ is the total number of discharge records, and $q_{i}$ is the $i$ th measured discharge of a stream, and $q_{i-1}$ is the $i-1$ th measured discharge of a stream.

The runoff ratio is the total discharge depth divided by total precipitation depth, which indicates the proportion of precipitation that is discharged in surface channels. A higher value of runoff ratio indicates an increase of surface runoff and may result in decreases in groundwater level because of less infiltration (Foster and Chilton, 2004).

\subsection{Evaluation of model uncertainty}

Because we manually calibrated the models, we also analyzed uncertainty associated with three of the model input parameters, by varying sub-catchment width by $\pm 10 \%$ (Gironas et al., 2009), and by varying Manning's $n$ to test two plausible end values for pervious surfaces $(0.2$ and 0.5$)$ and natural channels (0.04 and 0.055) (Chow, 1959). We chose these parameters because they were likely to have the greatest impact on simulated discharge events during the manual calibration process. Given that SWMM is run through a GUI, extensive analyses were not practical, so we assessed one watershed (WS 4, which was used in the largest number of scenarios) and tested uncertainty by changing one of these parameters at a time while holding all others constant. We used unit-area peak discharge to measure changes in model results, and $R^{2}$ and NSE to evaluate model performance as we did for calibration and validation.

\section{Results}

\subsection{Calibration and validation of the Storm Water Management Model}

Calibrated model parameters (Table 3 ) were used to generate hydrographs for each watershed (Fig. 3). Generally, calibration and validation hydrographs demonstrated acceptable fit between observed and simulated discharge, although some differences in timing (WS5, calibration) and/or magnitude 
Table 2. Current and predicted scenarios for SWMM model simulation using current (2011) and future (2040) climate and land cover conditions for five watersheds in central Iowa. The different distributions of land cover change (partial) were only applied to the fourth watershed (WS4).

\begin{tabular}{lllll}
\hline & Watersheds included & Scale of simulation & Land cover year & Climate year \\
\hline $\begin{array}{l}\text { Current condition } \\
\text { Predicted scenarios }\end{array}$ & All & Whole watershed & 2011 & 2011 \\
Climate & All & Whole watershed & 2011 & 2040 \\
Land cover & All & Whole watershed & 2040 & 2011 \\
Climate and land cover & All & Whole watershed & 2040 & 2040 \\
Land cover (partial) & WS4 & Subsection, downstream area & 2040 & 2040 \\
Land cover (partial) & WS4 & Subsection, midstream area & 2040 & 2040 \\
Land cover (partial) & WS4 & Subsection, upstream area & 2040 & 2040 \\
\hline
\end{tabular}

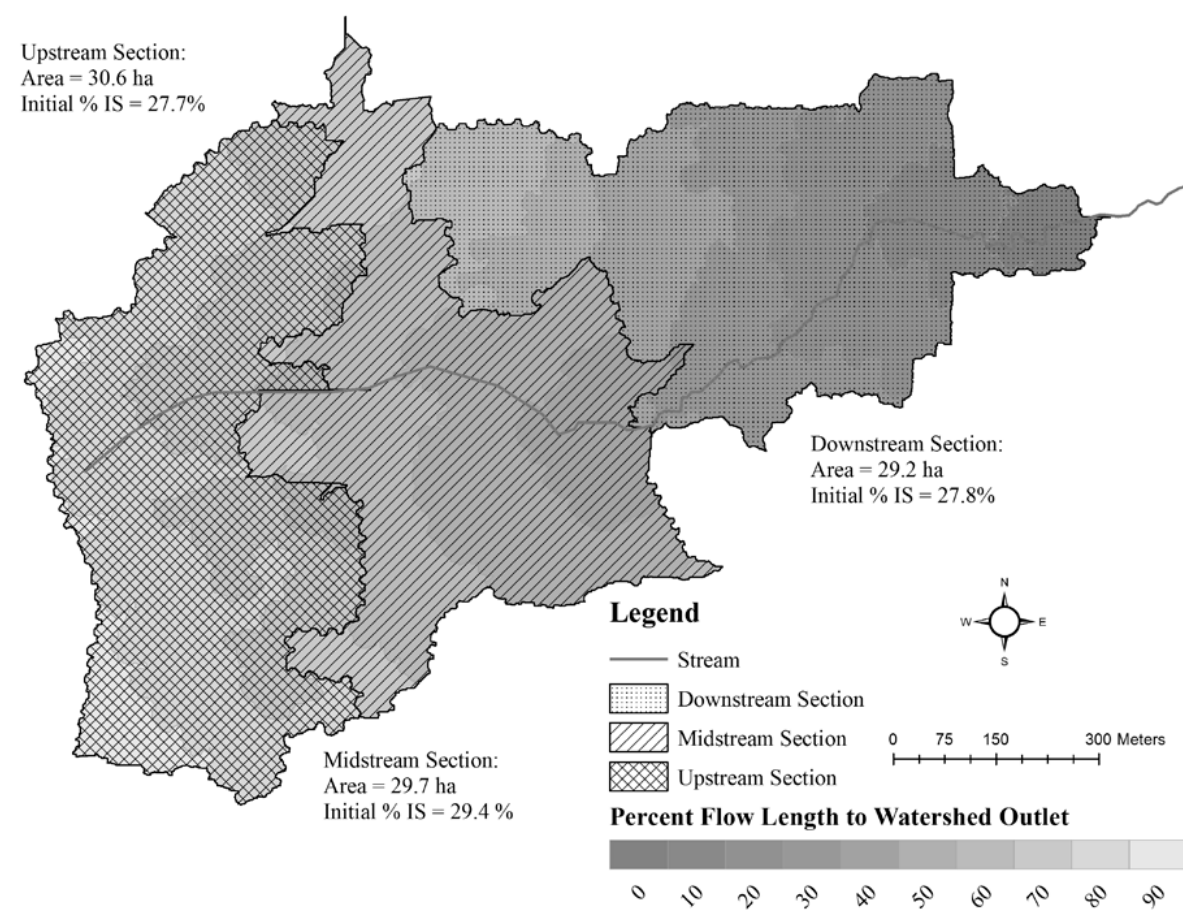

Fig. 2. Boundaries of the three sections for the different distributions of impervious land cover scenario for WS4. The three sections have similar area and percent impervious surface in 2011 (initial \% IS). The downstream section includes 0 to $40 \%$ of flow length to the outlet, the midstream section includes 40 to $70 \%$, and the upstream section includes 70 to $100 \%$ of flow length to the outlet.

(WS1, validation) were observed. For calibration simulations, coefficients of determination ranged from 0.73 to 0.89 , and NSEs ranged from 0.25 to 0.80 (Fig. 3). Coefficients of determination for validation simulations ranged from 0.39 to 0.92 , and NSEs ranged from 0.23 to 0.91 . Among the models, validation statistics were somewhat lower (although still acceptable as per Moriasi et al., 2007) for watershed WS1.

\subsection{Current condition simulation}

Current condition simulations describe existing (2011) hydrological dynamics for the five watersheds (Table 4). Compared to other watersheds, WS1 was character- ized by the lowest values for unit-area peak discharge $\left(0.29 \times 10^{-6} \mathrm{~m} \mathrm{~s}^{-1}\right), R-B$ Index (flashiness; 0.015), and runoff ratio $(0.053)$. As \% IS increased, watershed simulations generated consistently greater values for all three indices. In WS5, the three indices were $2.33 \times 10^{-6} \mathrm{~m} \mathrm{~s}^{-1}$, 0.130 , and 0.355 , respectively, five to seven times greater than those for WS1.

\subsection{Independent and combined effects of climate and land cover change simulations}

In the climate change scenario, an $18 \%$ increase in precipitation generated increases in all three hydrological indices 




Fig. 3. Hydrograph segments for calibration (left column) and validation (right column) of the five models (WS1 to WS5). Discharge was standardized by watershed area.

Table 3. Calibrated SWMM model parameters for five watersheds (WS1 to WS5) in central Iowa. A1, B1, A2, and B2 are coefficients for the groundwater equation in SWMM.

\begin{tabular}{lrrrrr}
\hline Parameters and Statistics & WS1 & WS2 & WS3 & WS4 & WS5 \\
\hline Number of sub-catchments & 29 & 32 & 49 & 52 & 60 \\
Average width of sub-catchments (m) & 704 & 259 & 324 & 101 & 123 \\
Manning's $n$ (impervious surfaces) & 0.017 & 0.05 & 0.05 & 0.05 & 0.05 \\
Manning's $n$ (pervious surfaces) & 0.18 & 0.5 & 0.2 & 0.4 & 0.4 \\
Manning's $n$ (channels: natural) & 0.05 & 0.05 & 0.04 & 0.05 & 0.04 \\
Manning's $n$ (channels: storm sewer) & - & - & 0.012 & 0.012 & 0.012 \\
Manning's $n$ (channels: gutter) & 0.015 & - & 0.015 & 0.015 & 0.015 \\
Parameters for groundwater equation & & & & & \\
A1 & 0.0005 & 0.050 & 0.0070 & 0.050 & 0.008 \\
B1 & 1.00 & 1.00 & 2.00 & 1.00 & 1.00 \\
A2 & 0.0005 & 0.007 & 0.0010 & 0.050 & 0.008 \\
B2 & 1.00 & 1.00 & 1.00 & 1.00 & 1.00 \\
\hline
\end{tabular}


Table 4. Hydrological response characteristics for current condition, climate change, land cover change, and combined scenarios for five watersheds (WS1 to WS5) in central Iowa. The relative changes in percent for climate, land cover and combined scenarios are calculated compared to the current condition.

\begin{tabular}{|c|c|c|c|c|c|c|}
\hline Scenarios & Indices & WS1 & WS2 & WS3 & WS4 & WS5 \\
\hline \multirow{3}{*}{ Current condition } & Unit-area peak discharge $\left(\times 10^{-6} \mathrm{~m} \mathrm{~s}^{-1}\right)$ & 0.29 & 0.88 & 1.37 & 1.62 & 2.33 \\
\hline & $R-B$ Index & 0.015 & 0.027 & 0.060 & 0.061 & 0.130 \\
\hline & Runoff ratio & 0.053 & 0.077 & 0.181 & 0.266 & 0.355 \\
\hline \multirow{6}{*}{ Climate } & Unit-area peak discharge $\left(\times 10^{-6} \mathrm{~m} \mathrm{~s}^{-1}\right)$ & 0.35 & 1.02 & 1.69 & 1.97 & 2.82 \\
\hline & Change $(\%)$ & 21.1 & 16.8 & 23.4 & 21.8 & 21.1 \\
\hline & $R-B$ Index & 0.015 & 0.027 & 0.061 & 0.066 & 0.136 \\
\hline & Change $(\%)$ & 1.7 & 2.0 & 2.0 & 8.3 & 4.7 \\
\hline & Runoff ratio & 0.053 & 0.077 & 0.181 & 0.268 & 0.358 \\
\hline & Change (\%) & 0.0 & 0.6 & 0.1 & 0.7 & 0.7 \\
\hline \multirow{6}{*}{ Land cover } & Unit-area peak discharge $\left(\times 10^{-6} \mathrm{~m} \mathrm{~s}^{-1}\right)$ & 0.58 & 1.17 & 2.03 & 2.37 & 2.80 \\
\hline & Change $(\%)$ & 99.7 & 33.7 & 47.8 & 46.4 & 20.1 \\
\hline & $R-B$ Index & 0.019 & 0.037 & 0.102 & 0.091 & 0.148 \\
\hline & Change $(\%)$ & 27.2 & 38.5 & 68.4 & 48.5 & 14.1 \\
\hline & Runoff ratio & 0.105 & 0.152 & 0.350 & 0.424 & 0.430 \\
\hline & Change $(\%)$ & 97.8 & 97.9 & 93.6 & 59.1 & 21.0 \\
\hline \multirow{6}{*}{ Climate and land cover } & Unit-area peak discharge $\left(\times 10^{-6} \mathrm{~m} \mathrm{~s}^{-1}\right)$ & 0.69 & 1.37 & 2.46 & 2.92 & 3.40 \\
\hline & Change $(\%)$ & 138.0 & 56.9 & 79.8 & 80.0 & 46.0 \\
\hline & $R-B$ Index & 0.019 & 0.038 & 0.101 & 0.098 & 0.156 \\
\hline & Change $(\%)$ & 29.9 & 40.9 & 66.9 & 60.0 & 20.7 \\
\hline & Runoff ratio & 0.105 & 0.153 & 0.351 & 0.427 & 0.433 \\
\hline & Change (\%) & 97.8 & 98.9 & 93.8 & 60.2 & 21.9 \\
\hline
\end{tabular}

compared to the current condition (e.g. Fig. 4 for WS4). Specifically, unit-area peak discharge for the five watersheds ranged from $0.35 \times 10^{-6} \mathrm{~m} \mathrm{~s}^{-1}$ to $2.82 \times 10^{-6} \mathrm{~m} \mathrm{~s}^{-1}$, an increase of $20.8 \%$ on average compared to current condition values (Table 4). The change in unit-area peak discharge was greatest in WS3 (23.4\%). Increases in $R-B$ Index and runoff ratio compared to current condition values were much smaller than those for unit-area peak discharge. On average, the $R-B$ Index increased $3.7 \%$, ranging from 0.015 to 0.136 , with the greatest proportional increase occurring in WS4 $(8.3 \%)$. Watersheds with higher \% IS generally had greater values for $R-B$ Index. Runoff ratio increased $0.4 \%$ on average, ranging from 0.053 to 0.358 , with the greatest proportional increases occurring in WS4 and WS5 $(0.7 \%)$.

A separate analysis (data not shown) of responses for the three indices in WS1 and WS4 to the storm event in the validation model (21.3-23.1 mm precipitation) indicated consistent trajectories of change for all three indices at both levels of initial IS beyond that tested in the climate change scenario (e.g. the precipitation gradient from $16.8 \mathrm{~mm}$ (current condition) to $19.8 \mathrm{~mm}$ (climate change scenario) and $23.1 \mathrm{~mm}$ for the validation scenario). The land cover change scenario led to a greater hydrological response compared to the current condition than did the climate change scenario (e.g. Fig. 4 for WS4). All three response indices increased to a greater degree than they did in the climate change scenario (Table 4). Unit-area peak discharge ranged from 0.58 to 2.80 (an average increase of $49.5 \%$ ). The greatest increase compared to the current condition (99.7\%) occurred in WS1. Increases in the $R-B$ Index ranged from 0.019 to 0.148 , with an average increase of $39.3 \%$. The greatest increase $(68.4 \%)$ occurred in WS3. Runoff ratio ranged from 0.105 to 0.430 , a $73.9 \%$ average increase, with the greatest increase $(97.9 \%)$ detected for WS2.

The combined effects of climate and land cover changes generated the largest changes in the hydrograph (e.g. Fig. 4 for WS4) and for all three indices (Table 4). Unit-area peak discharge increased from 0.69 to 3.40 , with an average increase of $80.1 \%$. The greatest increase $(138.0 \%)$ occurred in WS1. The $R-B$ Index ranged from 0.019 to 0.156 (an average increase of $43.7 \%$ ), with the largest increase $(66.9 \%)$ in WS3. The runoff ratio ranged from 0.105 to 0.433 (an average increase of $74.5 \%$ ), with the largest increase (98.9\%) in WS2.

\subsection{Simulations of different distributions of land cover change for WS4}

For different distributions of land cover change in WS4, we observed consistent increases but different patterns of change for each of the hydrological indices (Table 5). The unit-area peak discharge responded most strongly to additional \% IS in the midstream area, increasing by $18.4 \%$, compared to the other two scenarios (16.1\% and $15.6 \%$; Table 5). The response of the $R-B$ Index to greater \% IS in the upstream area was much lower $(12.0 \%)$ compared to the other two scenarios $(17.5 \%$ and $18.1 \%)$. Increases in runoff ratios were similar for the three scenarios (ranging from 19.3 to $20.2 \%$; Table 5). 


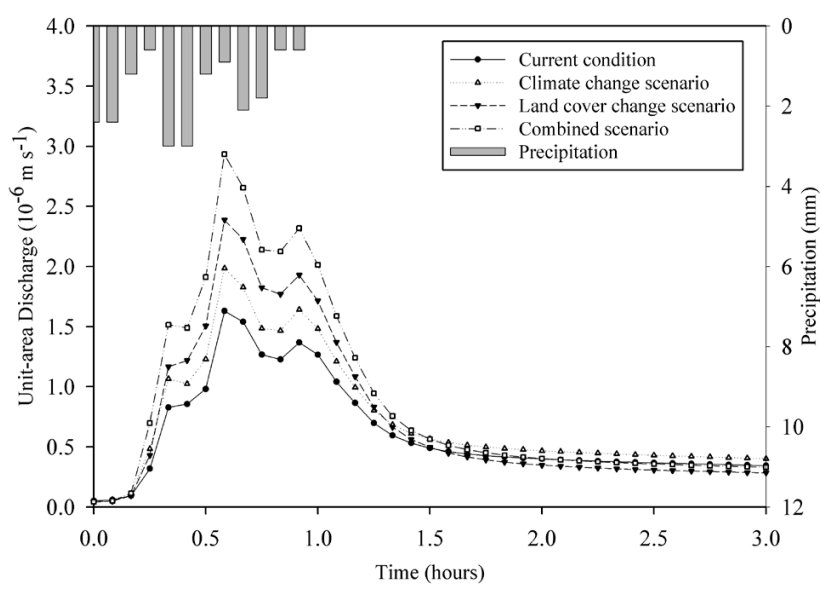

Fig. 4. Precipitation and hydrographs for the current condition, climate change, land cover change and combined climate and land cover change scenarios for WS4.

When urban land cover was added to the downstream portion of the watershed, the three indices increased $(16.1 \%$, $17.5 \%$, and $19.3 \%$, respectively) compared to the current condition. When urban land cover increased in the midstream area of the watershed, the unit-area peak discharge and $R-B$ Index increased the most of the three scenarios tested (18.4\% and $18.1 \%$, respectively). When urban land cover increased in the upstream portion of the watershed, runoff ratio increased the most among the three scenarios, from 0.268 to 0.322 (a $20.2 \%$ increase).

Hydrographs for the initial climate change scenario and the three different distributions of land cover change (Fig. 5) indicated that: (1) discharge rates increased more rapidly during the early stages (at $0.33 \mathrm{~h}$ ) of the downstream scenario (Box A), and discharge recession was slower for the upstream scenario (Box E); (2) lower peak discharge occurred for the upstream scenario at the first (Box B) and the third peak (Box D), linked to smaller increases in $R-B$ Index; and (3) the greatest overall unit-area peak discharge occurred during the second peak for all three scenarios, among which the midstream scenario generated the greatest unit-area peak discharge (Box C).

\subsection{Evaluation of model uncertainty}

Our analyses indicated that variation $( \pm 10 \%)$ in subcatchment width did not change model performance (as measured by $R^{2}$ and NSE), and caused very minor changes in unit area peak discharge (a $0.15 \%$ decrease with decreased width, and a $0.25 \%$ increase with greater width, Table 6 , Fig. 6). Changes to Manning's $n$ also had little effect: for pervious surfaces there were no changes, and for natural channels when Manning's $n$ was set at 0.04 , only unit area peak discharge changed, decreasing by $1.22 \%$. When the same parameter was increased to 0.055 , model $R^{2}$ decreased slightly to 0.90 , NSE decreased to 0.86 , and unit-area peak discharge decreased by $2.63 \%$ (Table 6 ).

\section{Discussion}

In this study, we calibrated and validated SWMM for each of five urban headwater stream watersheds that represent a gradient in \% IS. Calibration and validation of the five models demonstrated acceptable fit between measured and simulated discharge. The current condition simulation illustrated the influence of increased \% IS among these watersheds. Of the response metrics we analyzed, simulations of climate change had the greatest effect on unit-area peak discharge. Simulations of land cover change led to relatively large increases in all three hydrological indices. Simulations for combined climate and land cover change caused greater changes to the three hydrological indices than either climate or land cover change alone. Unit-area peak discharge and $R-B$ Index were the most sensitive to different spatial distributions of additional IS.

\subsection{Calibration and validation of the storm water management model}

Calibration and validation results indicated that SWMM was able to simulate hydrological processes in the small watersheds we studied, and was sensitive to the gradient in initial \% IS among them (Fig. 3). Of the five watersheds, WS1 and WS3 were separated by the greatest distance from a weather station (Table 1), which resulted in time lags between recorded and actual precipitation (Fig. 3) which led to the generally lower (but still acceptable) validation statistic values for these watersheds.

\subsection{Current condition simulations}

Current condition hydrological responses indicated that unitarea peak discharge, $R-B$ Index, and runoff ratio all increased along the \% IS gradient that characterized these watersheds (Table 4), a result that corroborates the hypotheses and work of a number of researchers (e.g. Arnold and Gibbons, 1996; Nagy et al., 2012; Schueler, 1994, Yang et al., 2010). However, although runoff ratio responds fairly linearly to increases in impervious surface, $R-B$ index and unit-area peak discharge do not, with disproportionately large responses between $5 \%$ and $10 \%$ IS, and again between $28 \%$ and $37 \%$ IS.

Among much earlier studies documenting the effects of $\%$ IS on urban streams, distinct hydrological impacts were reported to occur when watershed \% IS reached a threshold of 10\% (Arnold and Gibbons, 1996; Booth and Jackson, 1997; Schueler and Holland, 2000). We found important differences for all three hydrological response indices that were detectable between $5.30 \%$ IS (WS1) and 7.96\% IS (WS2), especially for unit-area peak discharge (Table 4). 
Table 5. Hydrological response characteristics for different distributions of land cover change in three sections (downstream, midstream, and upstream areas) of one watershed, WS4. The three simulations use the predicted (2040) climate parameters, percent changes for indices are compared to the initial climate change scenario for that watershed.

\begin{tabular}{lrrrr}
\hline & $\begin{array}{r}\text { Initial Climate } \\
\text { Change Scenario }\end{array}$ & Downstream & Midstream & Upstream \\
\hline Unit-area peak discharge $\left(\times 10^{-6} \mathrm{~m} \mathrm{~s}^{-1}\right)$ & 1.97 & 2.29 & 2.33 & 2.28 \\
Change $(\%)$ & & 16.1 & 18.4 & 15.6 \\
$R-B$ Index & 0.066 & 0.078 & 0.078 & 0.074 \\
Change $(\%)$ & & 17.5 & 18.1 & 12.0 \\
Runoff ratio & 0.268 & 0.320 & 0.321 & 0.322 \\
Change $(\%)$ & & 19.3 & 19.6 & 20.2 \\
\hline
\end{tabular}

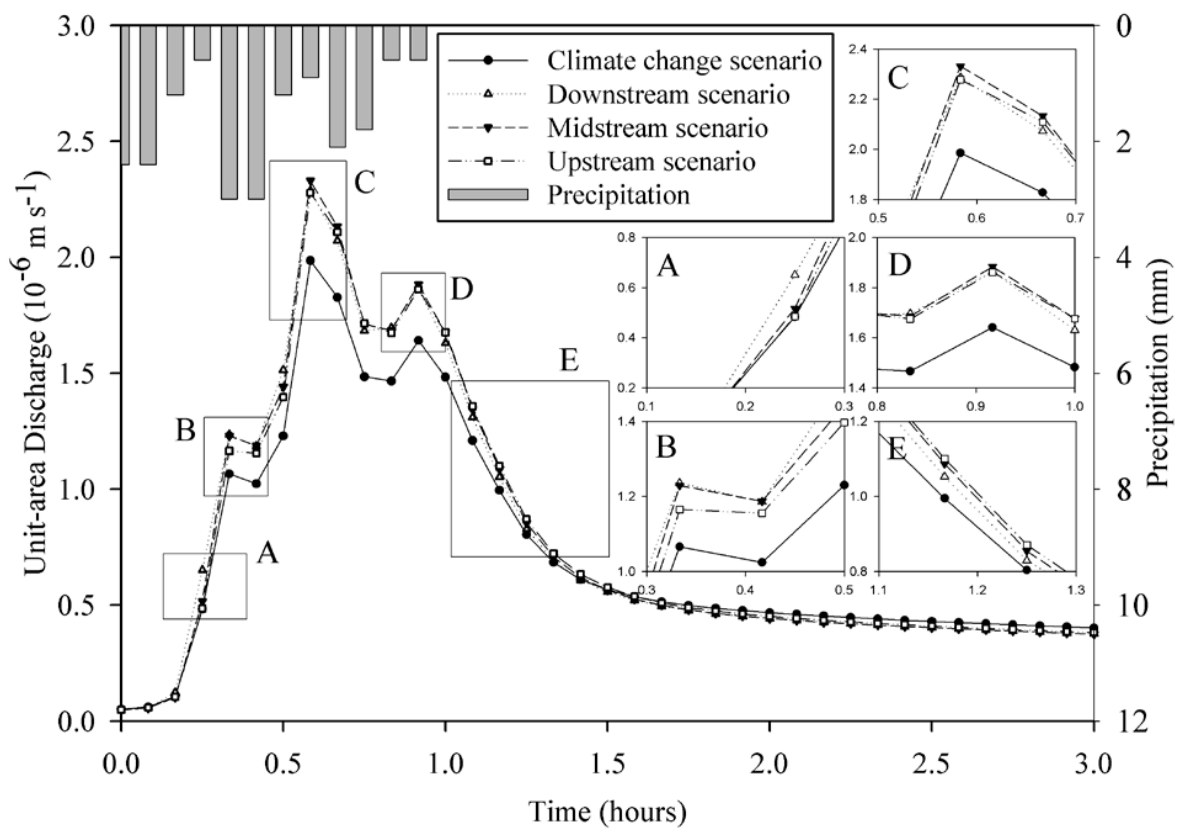

Fig. 5. Precipitation amounts and hydrographs for different distributions of land cover change for WS4. Discharge was standardized by watershed area. Box A illustrates greater discharge for the downstream scenario; Box B and Box D indicate lower peak discharge for the upstream scenario; Box C illustrates greatest peak discharge for the midstream scenario; and Box E indicates greater discharge for the upstream scenario.

These results indicate that important hydrological responses can occur below the often-cited threshold, in our case below $8 \%$ IS. Other researchers have also recently reported hydrological changes at relatively low \% IS in lower-order watersheds, suggesting threshold criteria of about $5 \%$ IS (based on 13 watersheds studied by Nagy et al., 2012 along the Florida Gulf Coast), or even $3 \%$ IS (based on 16 watersheds examined by Yang et al., 2010 in the White River basin in Indiana). It may be that focusing on small headwater streams allows detection of these effects at lower \% IS thresholds, or that these relatively small stream systems are more sensitive to $\%$ IS (Praskievicz and Chang, 2009).

A number of other factors important to urban stream hydrology include slope, distribution of IS, and storm sewer system density and structure (Booth and Jackson, 1997; Dingman, 2008; Meierdiercks et al., 2010; Mejia and Moglen, 2010). In spite of considerable variation in the aforementioned characteristics among the five watersheds we studied (Table 1), consistent changes in the three hydrological indices for these watersheds corresponding to the gradient in \% IS suggests that it can be a robust indicator of the effects of urban land cover on stream hydrology (as earlier suggested by Paul and Meyer, 2001, and Schueler et al., 2009).

\subsection{Climate change simulations}

In previous studies, hydrological impacts have been interpreted by determining changes in continuous discharge over 
Table 6. Uncertainty analyses for variations in sub-catchment width and Manning's $n$ (impervious surface and natural channels) for WS4. In each test run, only one parameter was changed and others were held constant.

\begin{tabular}{|c|c|c|c|c|c|c|c|}
\hline & $\begin{array}{r}\text { Current } \\
\text { condition value }\end{array}$ & Run 1 & Run 2 & Run 3 & Run 4 & Run 5 & Run 6 \\
\hline \multicolumn{8}{|l|}{ Parameters and statistics } \\
\hline Number of sub-catchments & 52 & & & & & & \\
\hline Average width of sub-catchments (m) & 101 & 90.9 & 111.1 & & & & \\
\hline Manning's $n$ (pervious surfaces) & 0.4 & & & 0.2 & 0.5 & & \\
\hline Manning's $n$ (channels: natural) & 0.05 & & & & & 0.04 & 0.055 \\
\hline \multicolumn{8}{|l|}{ Model performance statistics } \\
\hline$R^{2}$ & 0.92 & 0.92 & 0.92 & 0.92 & 0.92 & 0.92 & 0.90 \\
\hline NSE & 0.91 & 0.91 & 0.91 & 0.91 & 0.91 & 0.91 & 0.86 \\
\hline Unit-area peak discharge $\left(\times 10^{-6} \mathrm{~m} \mathrm{~s}^{-1}\right)$ & 1.01 & 1.01 & 1.02 & 1.01 & 1.01 & 1.00 & 0.99 \\
\hline Change in unit-area peak discharge $(\%)$ & & -0.15 & 0.25 & 0 & 0 & -1.22 & -2.63 \\
\hline
\end{tabular}

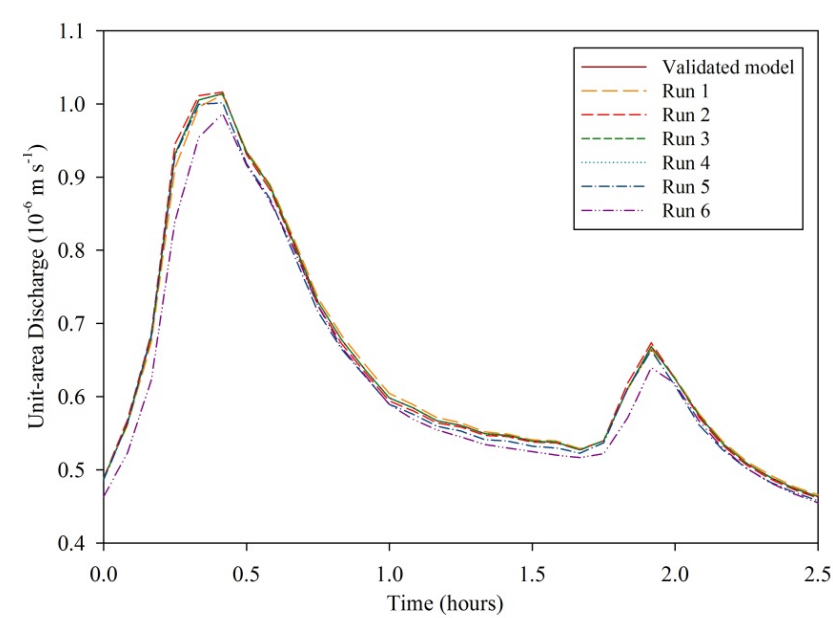

Fig. 6. Hydrographs for uncertainty analyses based on variations in sub-catchment width and Manning's $n$ (impervious surface and natural channels) for WS4.

relatively long timescales (e.g. Franczyk and Chang, 2009; Jha et al., 2004). In this study, however, we used single precipitation events to examine more detailed hydrological responses to climate change. The SWMM simulations we conducted indicate that climate change (increased precipitation with other factors held constant) will have greatest effects on unit-area peak discharge (20.8\% average increase) compared to $R-B$ Index (a $3.7 \%$ average increase) or runoff ratio (a $0.4 \%$ average increase). Examination of response indices for WS1 and WS4 for an extended precipitation gradient (to $23.1 \mathrm{~mm}$ ) indicated that unit-area peak discharge may not respond linearly to increasing precipitation, possibly owing to differences in storm sewer density and structure. We should note, though, that our ability to test responses by the three indices to a greater number of field observations of storm events was limited by the relatively brief (two-year) duration of our study, as well as variability in the characteristics of the events that occurred in that time frame (e.g. differences in duration of storm events, or multiple hydrograph peaks related to variation in precipitation rates within storm events). A longer period of study with more observations of a greater number of storm events would add to our understanding of how response variables are related to precipitation and impervious surface amounts. Notwithstanding these limitations, for already developed watersheds, stormwater mitigation strategies that address peak discharge rates should be a priority. A possible strategy that addresses peak discharge is stormwater system retrofitting to delay delivery (e.g. Karamouz et al., 2011), such as integration of wet ponds in a stormwater treatment train (e.g. Villarreal and Bengtsson, 2004). Increased precipitation resulted in greater response for all three indices along the gradient of \% IS from WS1 (5.30\% IS) to WS3 and WS4 (18.21 to $28.28 \%$ IS). Thus, at higher initial \% IS, stormwater management strategies to increase infiltration to mitigate potential increases in flashiness and runoff ratio become more important.

\subsection{Land cover change simulations}

Our watershed simulations for land cover change indicated that, compared to the climate change scenario, land cover change resulted in increased values for all three hydrological indices. In addition, the magnitude of stream responses to predicted land cover change in our study may underestimate actual responses, given that we did not project changes in the storm sewer conveyance system that would likely move precipitation more quickly to the stream. Our findings are generally consistent with previous reports for increases in peak discharge (from 30 to $100 \%$, e.g. Rose and Peters, 2001), runoff ratio (from 21 to $45 \%$, but more sensitive to watershed slope; Rose and Peters, 2001) and $R-B$ Index (15\%, Yang et al. (2010)) in response to greater amounts of impervious land cover. In their examination of small watersheds along 
the Gulf Coast, Nagy et al. (2012) reported greater effects of increasing \% IS on peak discharge, but lesser effects on $R-B$ Index. It is likely that the relative importance of changes in climate and land cover on stream hydrology are subject to the specifics of scenario designs (e.g. differing interpretations offered by Hamdi et al., 2011; Tong et al. 2012; Tu, 2009). Notwithstanding, our land cover change simulations provide further support for the contention that important hydrological changes occur at thresholds below $10 \%$ IS, based on consistent increases in all three response indices for the predicted impervious surface change from 5.30 to $10.47 \%$ in WS1 and from 7.96 to $15.74 \%$ in WS2.

\subsection{Combined climate and land cover change simulations}

The combined climate and land cover change simulations led to changes in response indices that were slightly greater than additive effects for climate and land cover change considered independently (Table 4). Further, hydrographs for WS4 (Fig. 4) indicate that runoff volume increases for each predictive scenario, most significantly for the combined effects of climate and land cover change. Although previous work has documented additive effects of combined climate and land cover changes (e.g. Nelson et al., 2009; Tong et al., 2012; Tu, 2009), conclusions about which influence might be stronger (either climate or land cover change) have been inconsistent, possibly owing to differences in prediction methods and the magnitude of relative changes in the projections used to make the predictions (Chang, 2003; Chen et al., 2005; Cuo et al., 2009; Davis Todd et al., 2007; Tang et al., 2005). For example, Tong et al. (2012) reported that climate change (assuming a $2 \%$ increase in temperature, and $20 \%$ increase in precipitation) led to a greater change in mean daily flow than did land cover change when both were projected to 2050 . However, when their climate change assumption was altered (to a $4 \%$ increase in temperature with associated increases in evaporation and evapotranspiration, and $20 \%$ increase in precipitation), the increase in mean daily flow due to climate change was less than that due to land cover change.

In our study, we projected a $1 \mathrm{~h}$ precipitation event with an $18 \%$ increase from a $16.8 \mathrm{~mm}$ (current condition) event to $19.8 \mathrm{~mm}$. The projected 2040 precipitation event was equivalent to a $1 \mathrm{~h}, 4$-month recurrence interval event in this region at the present time (Huff and Angel, 1992). We selected and projected this event relatively conservatively to avoid flooding during the simulations, which would preclude detection of changes in the response variables. Thus, although it appears that land use change has a stronger influence in our case, it may be only because the climate change scenario was constrained by the relatively small change to predicted precipitation.

\subsection{Simulations of different distributions of land cover change in WS4}

The differentially allocated land cover change scenarios for WS4 indicated that, although all three hydrological indices increased from the initial climate change scenario, only unitarea peak discharge and $R-B$ Index appeared to respond differently to increases in \% IS applied in the downstream, midstream, or upstream areas of the watershed. Thus, it appears that the location of IS additions primarily affects the timing, rather than amount, of discharge conveyed to the watershed outlet (e.g. WS4 curve in Fig. 5, where Box A indicates greater unit-area discharge early in the storm event for the downstream scenario due to the short path to the watershed outlet, and Box E indicates a slower recession for the upstream scenario due to a longer flow path).

Assuming a given increase of $\%$ IS in a watershed, any scenario that minimizes increases in peak discharge and flashiness would be better for the in-stream environment, since greater values for these indices are related to stream dynamics that can cause bank erosion and lead to poorer quality aquatic habitat (Walsh et al., 2005; Wenger et al., 2009). Thus, given the existing IS distribution and stormwater conveyance structures, addition of impervious surfaces in the upstream section of WS4 would have local effects within that portion of the stream, but would likely have less impact on stream hydrology and ecology at a whole-watershed scale. Using an urban hydrological model (e.g. SWMM in our study) to assess scenarios for future urban development in a range of watershed types could provide land use planners with critical information for decision-making to better protect urban streams.

\subsection{Model uncertainty}

There is uncertainty associated with predictive hydrological modeling for both single events (e.g. Zhao et al., 2013) and across longer time spans (e.g. Jung et al., 2011). Because we focus on small watersheds and have relatively highresolution data for their biophysical characteristics, we used the approach of carefully calibrating and validating the models to control for some of this uncertainty, and we used conservative model parameters for our projections that have also been used in previous studies (Chow, 1959; Gironás et al., 2009; Meierdiercks et al., 2010). Our uncertainty analyses, based on causing variation in sub-catchment width and Manning's $n$ for both pervious surfaces and natural channels indicated that these parameters have little effect on one of our response variables and on model performance as measured by standard statistics. However, we also acknowledge the likely importance of several sources of uncertainty (as per Jung et al., 2011), including that due to natural variability, future precipitation projections, other hydrological parameters within the model, and land cover change projections. 


\section{Conclusions}

We used SWMM to simulate hydrological responses of five headwater streams to increases in precipitation and urban land cover based on projections to the year 2040. We conclude that:

1. The current condition simulations indicated that watersheds that have greater $\%$ IS are also characterized by greater values in unit-area peak discharge, $R-B$ Index, and runoff ratio. Given variation in other important characteristics among the study watersheds (e.g. average slope, watershed size, and drainage density) $\%$ IS was a reliable indicator of impacts on urban stream hydrology. Efforts to mitigate negative impacts to stream hydrology in urban areas should include specific attention to strategies that limit additional IS and that minimize connectivity among existing impervious surfaces. We also detected important hydrological responses below the often-cited $10 \%$ IS threshold, in our case below $8 \%$ IS.

2. The climate change scenario in this study had strongest effects on unit-area peak discharge in these watersheds. All three hydrological indices were affected by the land cover change scenarios used in this study. The combined climate and land cover change scenarios resulted in slightly more than additive effects from climate and land cover change alone. These findings confirmed that urban stream hydrology, especially for unit-area peak discharge, is highly sensitive to expected changes in climate and land cover. The capacity of existing stormwater drainage/infiltration systems should be continuously evaluated and incorporated in comprehensive planning at municipal and regional levels.

3. Simulations for different distributions of land cover change demonstrated that the location of IS additions has a greater effect on the timing of delivery than on total amount of discharge. The ability to detect hydrological impacts associated with specific placement of impervious surfaces indicates that this simulation method could be very useful in identifying locations for development that would minimize stream degradation at a whole-watershed scale in small urban watersheds.

The result that hydrological responses of these streams to projected land cover changes were much greater than those generated by projected climate change is due, in part, to the conservative approach to climate change that we used to develop the models. In spite of this limitation, simulations for this set of watersheds indicated that plausible changes in both climate and land cover will have strong effects on urban stream hydrology. In addition, simulations for different distributions of IS in WS4 were also constrained by pre-existing
IS and stormwater conveying systems in that watershed. In spite of these limitations, this study extends our knowledge of the hydrological dynamics of lower-order urban streams, and elucidates several potential cause and effect relationships that can be used to manage urban landscapes to reduce negative impacts to urban stream ecosystems.

\section{Supplementary material related to this article is available online at http://www.hydrol-earth-syst-sci.net/ 17/4743/2013/hess-17-4743-2013-supplement.pdf.}

Acknowledgements. We would like to thank A. Whipple, City of Des Moines, for access to land cover data, and city staff members in Altoona, A. Johnston, and Pleasant Hill for their help in obtaining storm sewer data. This research was supported by the Chinese Scholarship Council, the Center for Global and Regional Environmental Research at the University of Iowa, the State of Iowa, and McIntire-Stennis funding.

Edited by: A. Gelfan

\section{References}

Anderson, D. G.: Effects of urban development on floods in Northern Virginia, United States Government Printing Office, Washington, DC, 1970.

Arnold, C. L. and Gibbons, C. J.: Impervious surface coverage The emergence of a key environmental indicator, J. Am. Plann. Assoc., 62, 243-258, 1996.

Baker, D. B., Richards, R. P., Loftus, T. T., and Kramer, J. W.: A new flashiness index: Characteristics and applications to midwestern rivers and streams, J. Am. Water Resour. As., 40, 503-522, 2004.

Bicknell, B. R., Imhoff, J. C., Kittle, Jr., J. L., Donigian, Jr., A. S., and Johanson, R. C.: Hydrological Simulation Program - Fortran, User's manual for version 11. EPA/600/R-97/080, US Environmental Protection Agency, National Exposure Research Laboratory, Athens, GA, 1997.

Black, R. W., Moran, P. W., and Frankforter, J. D.: Response of algal metrics to nutrients and physical factors and identification of nutrient thresholds in agricultural streams, Environ. Monit. Assess., 175, 397-417, 2011.

Booth, D. B. and Jackson, C. R.: Urbanization of aquatic systems: Degradation thresholds, stormwater detection, and the limits of mitigation, J. Am. Water Resour. As., 33, 1077-1090, 1997.

Bowman, T. A., Thompson, J. R., Tyndall, J. C., and Anderson, P. F.: Land cover analysis for urban foresters and municipal planners, examples from Iowa, J. Forest., 110, 25-33, 2012.

Boyle, J. S.: Evaluation of the annual cycle of precipitation over the United States in GCMs: AMIP simulations, J. Climate, 11, 1041-1055, 1998.

Chang, H.: Basin hydrologic response to changes in climate and land use, The Conestoga River Basin, Pennsylvania, Phys. Geogr, 24, 222-247, 2003.

Chen, J. F., Li, X. B., and Zhang, M.: Simulating the impacts of climate variation and land-cover changes on basin hydrology, A 
case study of the Suomo basin, Sci. China Ser. D., 48, 15011509, 2005.

Choi, W.: Catchment-scale hydrological response to climate-landuse combined scenarios: a case study for the Kishwaukee River Basin, Illinois, Phys. Geogr., 29, 79-99, 2008.

Chow, V. T.: Open-Channel Hydraulics, McGraw-Hill Book Co., New York, 1959.

Chung, E., Park, K., and Lee, K.: The relative impacts of climate change and urbanization on the hydrological response of a Korean urban watershed, Hydrol. Process., 25, 544-560, 2011.

Cuo, L., Lettenmaier, D. P., Alberti, M., and Richey, J. E.: Effects of a century of land cover and climate change on the hydrology of the Puget Sound basin, Hydrol. Process., 23, 907-933, 2009.

Davis Todd, C. E., Goss, A. M., Tripathy, D., and Harbor, J. M.: The effects of landscape transformation in a changing climate on local water resources, Phys. Geogr., 28, 21-36, 2007.

Denault, C., Millar, R. G., and Lence, B. J.: Assessment of possible impacts of climate change in an urban catchment, J. Am. Water Resour. As., 42, 685-697, 2006.

Dingman, S. L.: Physical hydrology, Waveland Pr. Inc., Long Grove, Illinois, 2008.

Eastman, J. R.: IDRISI Selva, Computer software program produced by Clark University, Worcester, MA, 2012.

Foster, S. S. D. and Chilton, P. J.: Downstream of downtown, urban wastewater as groundwater recharge, Hydrogeol. J., 12, 115-120, 2004.

Franczyk, J. and Chang, H.: The effects of climate change and urbanization on the runoff of the Rock Creek basin in the Portland metropolitan area, Oregon, USA, Hydrol. Process., 23, 805-815, 2009.

GeoInformatics Training, Research, Education, and Extension (GeoTREE): Data available at: http://www.geotree.uni.edu/ extensions/iowa-lidar-mapping-project/ (last access: 10 April 2012), 2011.

Gironás, J., Roesner, L. A., and Davis, J.: Storm water management model applications manual, US Environmental Protection Agency, Cincinnati, OH, 2009.

Green, I. R. A.: An explicit solution of the modified Horton equation, J. Hydrol., 83, 23-27, 1986.

Grimm, N. B., Faeth, S. H., Golubiewski, N. E., Redman, C. L., Wu, J., Bai, X., and Briggs, J. M.: Global change and the ecology of cities, Science, 319, 756-760, 2008

Guneralp, B., Reilly, M. K., and Seto, K. C.: Capturing multiscalar feedbacks in urban land change: a coupled system dynamics spatial logistic approach, Environ. Plann. B., 39, 858-879, 2012.

Hamdi, R., Termonia, P., and Baguis, P.: Effects of urbanization and climate change on surface runoff of the Brussels Capital Region: a case study using an urban soil-vegetation-atmosphere-transfer model, Int. J. Climatol., 31, 1959-1974, 2011.

Hatt, B. E., Fletcher, T. D., Walsh, C. J., and Taylor, S. L.: The influence of urban density and drainage infrastructure on the concentrations and loads of pollutants in small streams, Environ. Manage., 34, 112-124, 2004.

Hsu, M. H., Chen, S. H., and Chang, T. J.: Inundation simulation for urban drainage basin with storm sewer system, J. Hydrol., 234, 21-37, 2000.

Huff, F. A. and Angel, J. R.: Rainfall frequency atlas of the Midwest, Midwestern Climate Center, NOAA, Champaign, Illinois, 1992.
Huong, H. T. L. and Pathirana, A.: Urbanization and climate change impacts on future urban flooding in Can Tho city, Vietnam, Hydrol. Earth Syst. Sci., 17, 379-394, doi:10.5194/hess-17-3792013, 2013.

Iowa Environmental Mesonet: Data available at: http://mesonet agron.iastate.edu/ (last access: 10 April 2012), 2012.

Jha, M., Pan, Z. T., Takle, E. S., and Gu, R.: Impacts of climate change on streamflow in the Upper Mississippi River Basin, A regional climate model perspective, J. Geophys. Res.-Atmos., 109, D09105, doi:10.1029/2003JD003686, 2004.

Jung, I.-W., Chang, H., and Moradkhani, H.: Quantifying uncertainty in urban flooding analysis considering hydro-climatic projection and urban development effects, Hydrol. Earth Syst. Sci., 15, 617-633, doi:10.5194/hess-15-617-2011, 2011.

Karamouz, M., Hosseinpour, A., and Nazif, S.: Improvement of urban drainage system performance under climate change impact, case study, J. Hydrol. Eng., 16, 395-412, 2011.

Kendon, E. J., Roberts, N. M., Senior, C. A., and Roberts, M. J.: Realism of rainfall in a very high-resolution regional climate model, J. Climate, 25, 5791-5806, 2012.

Meierdiercks, K. L., Smith, J. A., Baeck, M. L., and Miller, A. J.: Analyses of urban drainage network structure and its impact on hydrologic response, J. Am. Water Resour. As., 46, 932-943, 2010.

Mejia, A. I. and Moglen, G. E.: Impact of the spatial distribution of imperviousness on the hydrologic response of an urbanizing basin, Hydrol. Process., 24, 3359-3373, 2010.

Moriasi, D., Arnold, J., Van Liew, M., Bingner, R., Harmel, R., and Vieth, T.: Model evaluation guidelines for systematic quanitfication of accuracy in watershed simulations, T. ASABE, 50, 885900, 2007.

Nagy, R. C., Lockaby, B. G., Kalin, L., and Anderson, C.: Effects of urbanization on stream hydrology and water quality, the Florida Gulf Coast, Hydrol. Process., 26, 2019-2030, 2012.

National Climatic Data Center: Data available at http://www.ncdc.noaa.gov/temp-and-precip/time-series/ index.php?parameter $\$=\$ p c p\{\backslash \&\}$ month $\$=\$ 12\{\backslash \&\}$ year $\$=$ $\$ 2011\{\backslash \&\}$ filter $\$=\$ 12\{\backslash \&\}$ state $\$=\$ 13\{\backslash \&\} \operatorname{div} \$=\$ 5$ (last access: 20 July 2013), 2013.

Neitsch, S. L., Arnold, J. G., Kiniry, J. R., Srinivasan, R., and Williams, J. R.: Soil and Water Assessment Tool user's manual, TWRI Report TR-192, Texas Water Resources Institute, College Station, TX, 2002

Nelson, K. C., Palmer, M. A., Pizzuto, J. E., Moglen, G. E., Angermeier, P. L., Hilderbrand, R. H., Dettinger, M., and Hayhoe, K.: Forecasting the combined effects of urbanization and climate change on stream ecosystems: from impacts to management options, J. Appl. Ecol., 46, 154-163, 2009.

Paul, M. J. and Meyer, J. L.: Streams in the urban landscape, Annu. Rev. Ecol. Syst., 32, 333-365, 2001.

Pekarova, P. and Pekar, J.: The impact of land use on stream water quality in Slovakia, J. Hydrol., 180, 333-350, 1996.

Poelmans, L., Van Rompaey, A., Ntegeka, V., and Willems, P.: The relative impact of climate change and urban expansion on peak flows, a case study in central Belgium, Hydrol. Process., 25, 2846-2858, 2011

Praskievicz, S. and Chang, H.: A review of hydrologic modeling of basin-scale climate change and urban development impacts, Prog. Phys. Geogr. 33, 650-671, 2009. 
Quilbé, R., Rousseau, A. N., Moquet, J.-S., Savary, S., Ricard, S., and Garbouj, M. S.: Hydrological responses of a watershed to historical land use evolution and future land use scenarios under climate change conditions, Hydrol. Earth Syst. Sci., 12, 101-110, doi:10.5194/hess-12-101-2008, 2008.

Rantz, S. E.: Measurement and computation of streamflow, volume 1, Geological Survey Water-Supply Paper 2175, Washington, DC, 1982.

Rose, S. and Peters, N. E.: Effects of urbanization on streamflow in the Atlanta area (Georgia, USA): a comparative hydrological approach, Hydrol. Process., 15, 1441-1457, 2001.

Rossman, L. A.: Storm Water Management Model user's manual, US Environmental Protection Agency, Cincinnati, OH, 2010.

Schueler, T. R.: The importance of imperviousness, Watershed Protection Techniques, 1, 100-111, 1994.

Schueler, T. R. and Holland, H.: The practice of watershed protection: techniques for protecting our nation's streams, lakes, rivers, and estuaries, Center for Watershed Protection, Ellicott City, MD, 2000.

Schueler, T. R., Fraley-McNeal, L., and Cappiella, K.: Is impervious cover still important? A review of recent research, J. Hydrol. Eng., 14, 309-315, 2009.

State Data Center of Iowa: Data available at: http://www. iowadatacenter.org/ (last access on 10 April 2012), 2012.

Serneels, S. and Lambin, E. F.: Proximate causes of land-use change in Narok District, Kenya: a spatial statistical model, Agr. Ecosyst. Environ., 85, 65-81, 2001.

Shields, F. D., Lizotte, R. E., Knight, S. S., Cooper, C. M., and Wilcox, D.: The stream channel incision syndrome and water quality, Ecol. Eng., 36, 78-90, 2010.

Takle, E. S. and Herzmann, D.: Future climates for pavement performance analysis, Climate Science Program Report, Iowa State University, Ames, 2010.

Takle, E. S., Jha, M., Lu, E., Arritt, R. W., Gutowski, W. J., and the NARCCAP Team: Streamflow in the upper Mississippi river basin as simulated by SWAT driven by 20th-century contemporary results of global climate models and NARCCAP regional climate models, Meteorol. Z., 19, 341-346, 2010.

Tang, Z., Engel, B. A., Pijanowski, B. C., and Lim, K. J.: Forecasting land use change and its environmental impact at a watershed scale. J. Environ. Manage., 76, 35-45, 2005.

Tong, S. T. Y., Sun, Y., Ranatunga, T., He, J., and Yang, Y .J.: Predicting plausible impacts of sets of climate and land use change scenarios on water resources, Appl. Geogr., 32, 477-489, 2012.
Tu, J.: Combined impact of climate and land use changes on streamflow and water quality in eastern Massachusetts, USA, J. Hydrol., 379, 268-283, 2009.

US Environmental Protection Agency (US EPA): Storm Water Management Model (SWMM) Version 5.0.022, available at: http://www.epa.gov/nrmrl/wswrd/wq/models/swmm/ (last access 10 May 2012), 2011.

Villarreal, E. L. and Bengtsson, A.: Inner city stormwater control using a combination of best management practices, Ecol. Eng., 22, 279-298, 2004.

Violin, C. R., Cada, P., Sudduth, E. B., Hassett, B. A., Penrose, D. L., and Bernhardt, E. S.: Effects of urbanization and urban stream restoration on the physical and biological structure of stream ecosystems, Ecol. Appl., 21, 1932-1949, 2011.

Walsh, C. J., Roy, A. H., Feminella, J. W., Cottingham, P. D., Groffman, P. M., and Morgan, R. P.: The urban stream syndrome: current knowledge and the search for a cure, J. N. Am. Benthol. Soc., 24, 706-723, 2005.

Walsh, C. J., Sharpe, A. K., Breen, P. F., and Sonneman, J. A.: Effects of urbanization on streams of the Melbourne region, Victoria, Australia. I. Benthic macroinvertebrate communities, Freshwater Biol., 46, 535-551, 2001.

Wenger, S. J., Roy, A. H., Jackson, C. R., Bernhardt, E. S., Carter, T. L., Filoso, S., Gibson, C. A., Hession, W. C., Kaushal, S. S., Marti, E., Meyer, J. L., Palmer, M. A., Paul, M. J., Purcell, A. H., Ramirez, A., Rosemond, A. D., Schofield, K. A., Sudduth, E. B., and Walsh, C. J.: Twenty-six key research questions in urban stream ecology, an assessment of the state of the science, J. N. Am. Benthol. Soc., 28, 1080-1098, 2009.

Yang, G. X., Bowling, L. C., Cherkauer, K. A., Pijanowski, B. C., and Niyogi, D.: Hydroclimatic response of watersheds to urban intensity, an observational and modeling-based analysis for the White River Basin, Indiana, J. Hydrometeorol., 11, 122-138, 2010.

Zhao, D. Q., Chen, J. N., Wang, H. Z., and Tong, Q. Y.: Application of a sampling based on the combined objectives of parameter identification and uncertainty analysis of an urban rainfall-runoff model, J. Irrig. Drain. E.-ASCE, 139, 66-74, 2013. 